\title{
Correlation and Path Analysis Studies in Medium Duration Rice Varieties of Andhra Pradesh
}

\author{
Gayathri NK ${ }^{* 1}$ and Padmalatha $\mathrm{Y}^{2}$
}

${ }^{1}$ Acharya N.G.Ranga Agricultural University, Regional Agricultural Research Station, Nandyal, Kurnool, Andhra Pradesh, India

${ }^{2}$ Principal Scientist (Agronomy) \& Head, Agricultural Research Station, Garikapadu, Guntur, India

*Corresponding author: Gayathri NK, Scientist (Plant breeding), Acharya N.G.Ranga Agricultural University, Regional Agricultural Research Station, Nandyal, Kurnool, Andhra Pradesh, India, Tel: 9959885367, E-mail: gayathrirars@gmail.com

Citation: Gayathri NK (2018) Correlation and Path Analysis Studies in Medium Duration Rice Varieties of Andhra Pradesh. J Nutr Health Sci 5(3): 304. doi: 10.15744/2393-9060.5.304

Received Date: April 21, 2018 Accepted Date: September 11, 2018 Published Date: September 13, 2018

\begin{abstract}
The present investigation is carried out to study the correlation and path analysis in twenty five medium duration (120-125 days) varieties of rice (Oryza sativa L.). Character association of the yield attributing traits reveled significant positive association of grain yield per hectare with plant height, 1000 seed weight and panicle length. Hence selection in these traits can improve yield. In the present study high genetic coefficient of variation coupled with high heritability and high genetic advance was observed for number of seed/ panicle, hence there is scope for improvement of the trait through simple selection. Path coefficient analysis revealed that 1000 seed weight recorded maximum positive direct effect on yield followed by panicle length. Among these characters, 1000 seed weight and panicle length possessed both positive association and high direct effects. Hence selection for these characters could bring improvement in yield and yield components.
\end{abstract}

Keywords: Correlation; Path analysis; Heritability; Rice; Yield

\section{Introduction}

Rice (Oryza sativa $L$ ) is one of the pivotal staple cereal crops feeding more than half of the world's population. In view of the growing population the basic objective of all the plant breeders would be towards yield improvement. It has been estimated that the world will have to produce 60 per cent more rice by 2030 than what it produced in 1995 . Therefore increased production of rice plays a very important role in food security and poverty alleviation. Theoretically, rice still has great yield potential to be tapped and there are many ways to raise yield, such as building of irrigation works improvement of soil conditions, cultural techniques and breeding of high yielding varieties

Development of high yielding varieties requires information on association of characters contributing to yield in addition to their direct and indirect effects towards yield. This kind of analysis could help the breeder to design his selection strategies to improve grain yield. In this context the present investigation was carried out with the objective of studying the character association and path effects of yield components on grain yield in rice varieties of medium duration for their yield improvement. Earlier this work was reported by many researchers in various yield attributing characters like days to maturity [1-3], plant height [4-6], productive tiller/plant, panicle Length $[7,8]$ and 1000 seed weight $[6,9,10]$.

\section{Materials and Methods}

In the present investigation, 26 rice varieties of medium duration obtained from the rice research stations of Maruteru, Bapatla, Nellore, Khammam, Jagityal, Warangal, Nandyal and Rajendranagar of Acharya N.G. Ranga Agricultural University, Hyderabad were evaluated. Research stations form where the varieties were developed are furnished in Table 1.The seeds were sown during kharif'2013 at Regional Agricultural Research Station, Nandyal in a randomized block design with three replications. Further 20-30 days old seedling of each variety was transplanted in a $15 \mathrm{~m} 2$ plot at a spacing of $15 \mathrm{X} 20 \mathrm{~cm}$. All recommended packages of practices were followed along with nursery plant protection measures to raise a healthy crop. Observations were recorded on 
different parameters like days to $50 \%$ flowering, plant height number of effective tillers per plant, panicle length, number of seeds per panicle, 1000 seed weight $(\mathrm{g})$ and grain yield per ha and the data was subjected to statistical analysis, as per the procedures outlined for correlation coefficient [11] and path analysis [12] using software like Indostat Ver 8.5.

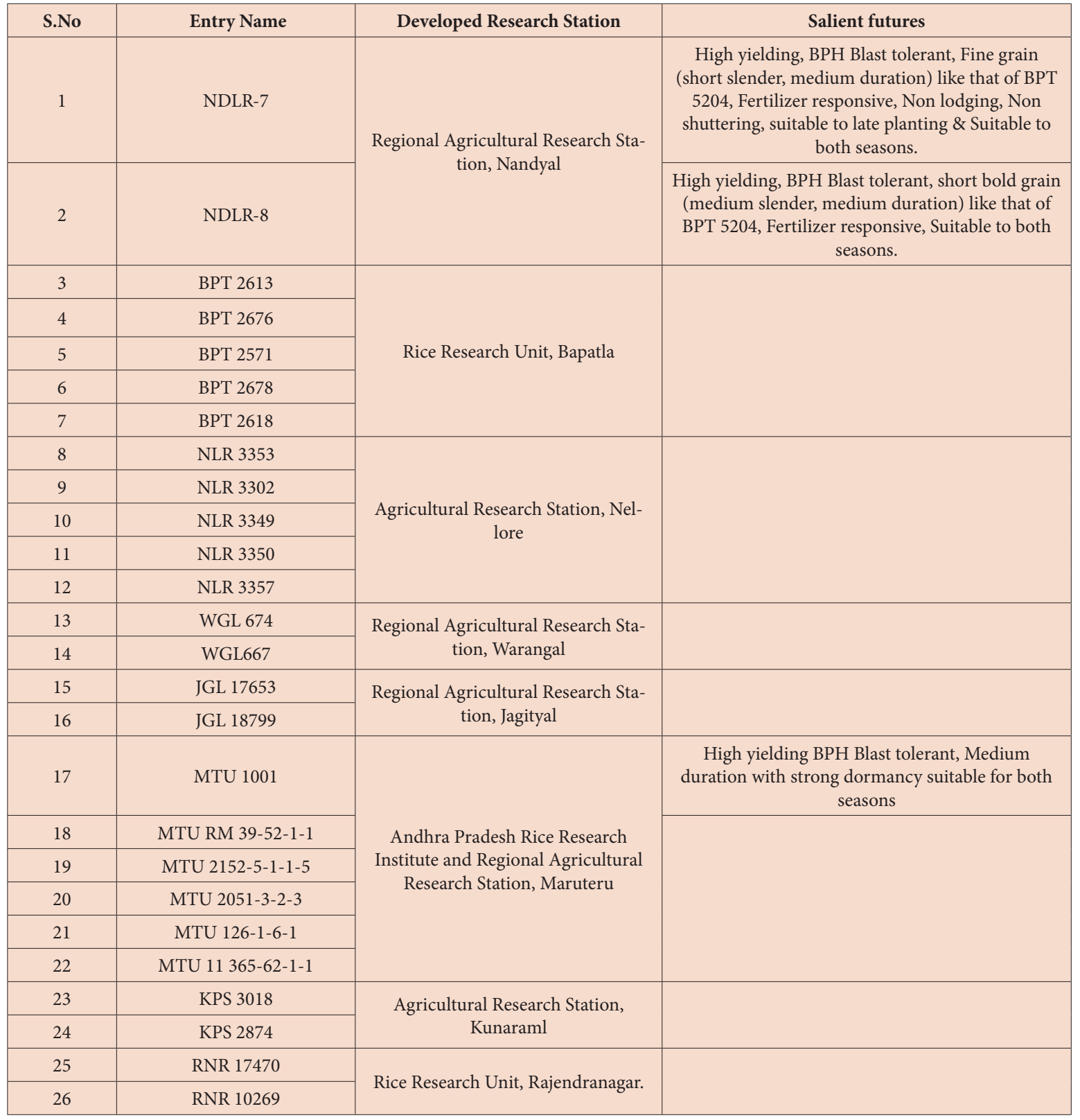

Table 1: Rice varieties developed from different research station of Andhra Pradesh

\section{Results and Discussion}

Effective selection depends on identifying key characters and knowledge on the magnitude and direction of association between yield and its attributing characters aid in effective selections and yield improvement. The analysis of variance for grain yield and yield attributing characters is presented in Table 2. A perusal of these results reveled the presence of significant differences among the genotypes studied indicating the effectiveness of selection for improvement of these traits. The data recorded on estimates of variability and genetic parameters for yield and yield attributing characters presented in Table 3 . An analysis of these results revealed wide range of variability for grain yield/ ha followed by effective tillers /plant. The phenotypic coefficient of variation (PCV) was observed to be higher than the genotypic coefficient of variation (GCV) for all traits studied in the present investigation, indicating the influence of environment. The extent of environmental influence (Environmental Coefficient of Variation: ECV) is explained by the amount of the difference between GCV and PCV and it ranged from 0.11 (Days to 50\% flowering) to 1.93 (Effective tillers/ plant) in the present study. Further high phenotypic and genotypic coefficient of variation was observed for number of seeds per panicle $(>20 \%)$.Therefore the characters, effective tiller per plant, 1000 seed weight and grain yield recorded moderate $(10-20 \%)$ estimates of genotypic and phenotypic estimates of variation. Low $(<10 \%)$ estimates of GCV and PCV were however observed for days to 50 per cent flowering, plant height and panicle length. 


\begin{tabular}{|c|c|c|c|c|c|c|c|c|}
\hline Source of variance & $\begin{array}{l}\text { Degrees of } \\
\text { freedom }\end{array}$ & $\begin{array}{c}\text { Days to } 50 \% \\
\text { flowering }\end{array}$ & $\begin{array}{l}\text { Plant } \\
\text { height }\end{array}$ & $\begin{array}{l}\text { Effective tillers for } \\
\text { Plant }\end{array}$ & Panicle length & $\begin{array}{l}\text { No.of seed/ } \\
\text { Panicle }\end{array}$ & $1000 \mathrm{SW}$ & Seed yield/ha \\
\hline Replication & 2 & 2.09 & 4.13 & 3.96 & 2.61 & 8.42 & $3.77^{* *}$ & 866576.81 \\
\hline Varieties & 25 & $60.46^{* *}$ & $129.85^{\star *}$ & $10.81^{* *}$ & $4.94^{\star \star}$ & $9307.31^{* *}$ & $26.94^{* *}$ & $1698480.99^{* *}$ \\
\hline Error & 50 & 3.08 & 10.70 & 3.11 & 1.67 & 131.89 & 0.53 & 404894.03 \\
\hline
\end{tabular}

${ }^{*}$ Significant at $\mathrm{P}=0.05$ and $\mathrm{P}=0.01$ levels respectively

Table 2: ANOVA table for yield and yield attributing characters of medium duration rice varieties

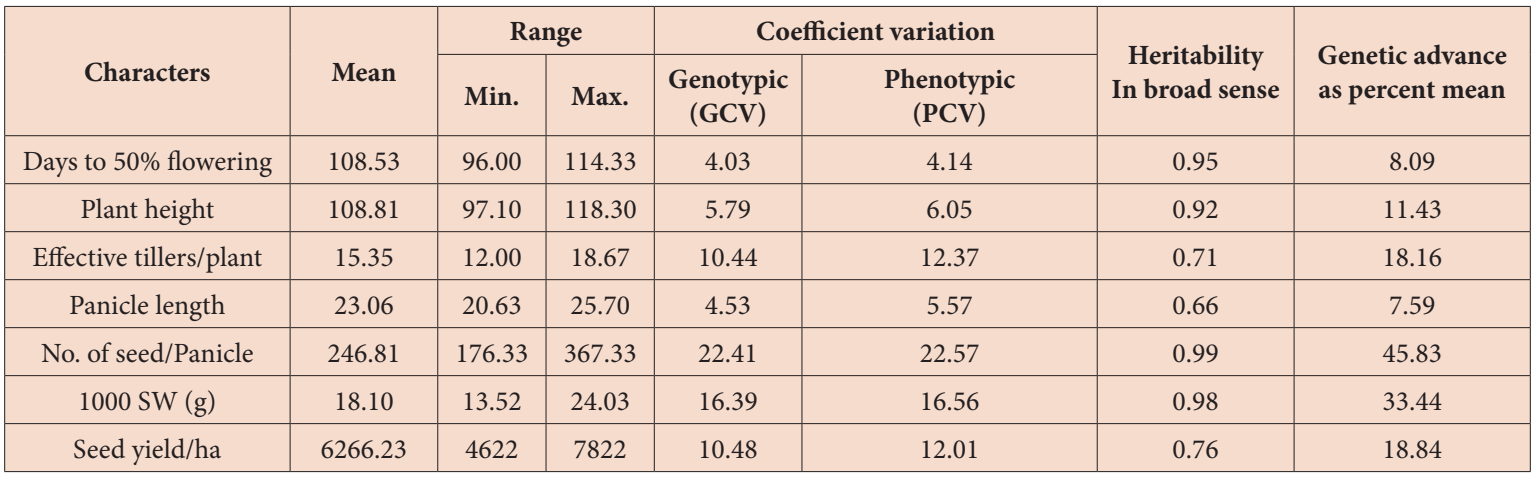

Table 3: Estimates the variability and genetic parameters for yield and yield attributing characters in medium duration rice

High heritability ( $>0.60$ ) was recorded for days to $50 \%$ flowering, plant height, number of effective tillers per plant, panicle length, number of seeds per panicle, 1000 seed weight and grain yield. The findings are in accordance with the results [13] who reported moderate PCV and GCV for productive tillers per plant and high heritability with moderate genetic advance with respect to days to maturity. The results on genetic advance as percent mean revealed high estimates ( $>20 \%)$ for number of seeds per panicle and 1000 seed weight. The findings are in agreement with the reports [14] who recorded higher PCV, GCV with high heritability and high genetic advance with respect to filled grains per panicle. However moderate estimates (10-20\%) were recorded for plant height and productive tillers per plant with moderate heritability and high genetic advance [15] and with high GCV and PCV coupled with high heritability and genetic advance with effective tillers per plant and grain yield [16] while low estimates $(<10 \%)$ were recorded for days to 50 per cent flowering and panicle length with low PCV and GCV coupled with high heritability and moderate genetic advance [13].

High heritability coupled with high genetic advance as percent mean was recorded for number of filled grains per panicle and 1000 seed weight in the present study indicating that these characters are governed by additive gene action and therefore simple selection would be effective for improvement of these characters. These findings are in agreement with the reports of moderate PCV and GCV coupled with high heritability and genetic advance with respect to 1000 seed weight [14,17]. High heritability with moderate genetic advance as percent mean was recorded for plant height, effective tillers per plant and grain yield indicating that heritability for these triats was due to both additive and non additive gene effects and hence simple selection may not be effective for improvement of these characters. The results are in agreement with the reports for plant height [14] and for effective tillers per plant and grain yield [16]. Further the characters namely days to $50 \%$ flowering and panicle length had recorded high heritability coupled with low genetic advance as percent mean indicating the predominant role of non additive gene effects such as epispastics and dominance. Similar results were reported earlier $[8,18]$ who reported that information on genetic variation along with heritability and genetic advance estimates would give better idea about the efficacy of selection. In the present study high GCV and PCV coupled with high heritability and high genetic advance as percent mean was observed for number of seeds per panicle indicating the preponderance of additive gene action and a scope for improvement of the trait through simple selection. These results are in conformity with reports [10].

Phenotypic and genotypic correlation between yield and yield components are presented in Table 4 . The results revealed that higher estimates of genotypic coefficients, compared to phenotypic coefficients for most of the characters studied indicating the masking modifying effects of environments and similar results were reported [8]. Further effective tillers per plant had recorded negative and significant correlation with panicle length probably due to competition for a common possibility such as nutrient supply indicating the need for balanced selection while effecting improvement for these traits. These findings are in conformity with the reports $[2,19]$ who recorded positive and significant correlation with respect to filled grains per panicle and plant height whereas days to 50 per cent flowering had recorded positive and significant correlation with plant height, 1000 seed weight and panicle length [20]. Further 1000 seed weight, panicle length and plant height had also recorded positive and significant correlation with grain yield indicating an increase in yield with an increase in these characters. Therefore, priority should be given to these traits, while making selection for yield improvement. These findings are in agreement with the reports [6] which recorded positive and significant correlation with respect to filled grains per panicle and 1000 seed weight. 


\begin{tabular}{|c|c|c|c|c|c|c|c|}
\hline Character & $\begin{array}{l}\text { Effective till- } \\
\text { ers for Plant }\end{array}$ & $\begin{array}{c}\text { Days to } 50 \% \\
\text { flowering }\end{array}$ & $\begin{array}{r}1000 \\
\text { SW }\end{array}$ & $\begin{array}{l}\text { Panicle } \\
\text { length }\end{array}$ & $\begin{array}{c}\text { Plant } \\
\text { height }\end{array}$ & $\begin{array}{l}\text { No. of seed } \\
\text { /Panicle }\end{array}$ & $\begin{array}{c}\text { Seed yield } \\
\text { /ha }\end{array}$ \\
\hline Effective tillers for Plant & $\begin{array}{c}1.000 \\
(1.000)\end{array}$ & $\begin{array}{c}-0.0504 \\
(-0.0795)\end{array}$ & $\begin{array}{c}-0.5582 \\
(-0.6580)\end{array}$ & $\begin{array}{l}-0.3163^{* *} \\
(-0.5765)\end{array}$ & $\begin{array}{c}-0.0211 \\
(-0.0103)\end{array}$ & $\begin{array}{c}-0.0122 \\
(-0.0179)\end{array}$ & $\begin{array}{c}-0.1434 \\
(-0.1566)\end{array}$ \\
\hline Days to $50 \%$ flowering & & $\begin{array}{c}1.000 \\
(1.000)\end{array}$ & $\begin{array}{c}0.0916 \\
(0.0946) \\
\end{array}$ & $\begin{array}{c}-0.0658 \\
(-0.1139)\end{array}$ & $\begin{array}{l}0.2880^{*} \\
(0.3131)\end{array}$ & $\begin{array}{c}-0.1835 \\
(-0.1927)\end{array}$ & $\begin{array}{c}-0.1311 \\
(-0.1550)\end{array}$ \\
\hline $1000 \mathrm{SW}$ & & & $\begin{array}{l}1.000 \\
(1.000)\end{array}$ & $\begin{array}{c}0.0752 \\
(0.1069)\end{array}$ & $\begin{array}{c}0.0082 \\
(0.0022)\end{array}$ & $\begin{array}{c}-0.4107 \\
(-0.4168)\end{array}$ & $\begin{array}{l}0.3261^{* *} \\
(0.3926)\end{array}$ \\
\hline Panicle length & & & & $\begin{array}{c}1.000 \\
(1.000)\end{array}$ & $\begin{array}{c}0.2529^{*} \\
(0.2791)\end{array}$ & $\begin{array}{c}0.1737 \\
(0.2200) \\
\end{array}$ & $\begin{array}{l}0.2382^{*} \\
(0.3395) \\
\end{array}$ \\
\hline Plant height & & & & & $\begin{array}{c}1.000 \\
(1.000)\end{array}$ & $\begin{array}{l}0.2933^{* *} \\
(0.3025)\end{array}$ & $\begin{array}{l}0.2355^{\star} \\
(0.2901)\end{array}$ \\
\hline No. of seed/Panicle & & & & & & $\begin{array}{c}1.000 \\
(1.000)\end{array}$ & $\begin{array}{c}0.1810 \\
(0.2060)\end{array}$ \\
\hline Seed yield/ha & & & & & & & $\begin{array}{c}1.000 \\
(1.000)\end{array}$ \\
\hline
\end{tabular}

${ }^{*}$ Significant at 1 percent level ${ }^{*}$ Significant at 5 percent level

Figures in parenthesis are genotypic correlation coefficients

Table 4: Estimates of phenotypic and genotypic correlation coefficient between yield and yield component characters of medium duration rice varieties

Among all the characters 1000 seed weight had the maximum positive effect on grain yield followed by panicle length [4].

Path co-efficient analysis provides an efficient means of finding out the direct and indirect causes of association and presents a critical examination of the specific forces acting to produce a given correlation and also measures the relative importance of each casual factor, hence the study of direct and indirect effects of yield components on grain yield was undertaken in the present investigation and the results obtained are presented in Table 5.

\begin{tabular}{|c|c|c|c|c|c|c|}
\hline Character & $\begin{array}{c}\text { Effective tillers } \\
\text { for Plant }\end{array}$ & $\begin{array}{c}\text { Days to 50\% } \\
\text { flowering }\end{array}$ & $\begin{array}{c}\mathbf{1 0 0 0} \\
\text { SW }\end{array}$ & $\begin{array}{c}\text { Panicle } \\
\text { length }\end{array}$ & $\begin{array}{c}\text { Plant } \\
\text { height }\end{array}$ & $\begin{array}{c}\text { No.of seed } \\
\text { /Panicle }\end{array}$ \\
\hline \multirow{2}{*}{ Effective tillers for Plant } & $\mathbf{0 . 2 4 4 5}$ & -0.0123 & -0.1365 & -0.0773 & -0.0052 & -0.0030 \\
& $\mathbf{( 1 . 3 0 5 1 )}$ & $(-0.1038)$ & $(-0.8587)$ & $(-0.7524)$ & $(-0.0135)$ & $(-0.0234)$ \\
\hline \multirow{2}{*}{ Days to 50\% flowering } & 0.0070 & $\mathbf{- 0 . 1 3 9 9}$ & -0.0128 & 0.0092 & -0.0403 & 0.0257 \\
& $(-0.0084)$ & $\mathbf{( 0 . 1 0 5 8 )}$ & $(0.0100)$ & $(-0.0120)$ & $(0.0331)$ & $(-0.0204)$ \\
\hline \multirow{2}{*}{ 1000 SW } & -0.3346 & 0.0549 & $\mathbf{0 . 5 9 9 4}$ & 0.0451 & 0.0049 & 0.2462 \\
& $(-0.9576)$ & $(0.1376)$ & $(\mathbf{1 . 4 5 5 4})$ & $(0.1555)$ & $(0.0032)$ & $(-0.6065)$ \\
\hline \multirow{2}{*}{ Panicle length } & -0.0534 & -0.0111 & 0.0127 & $\mathbf{0 . 1 6 8 8}$ & 0.0427 & 0.0293 \\
& $(-0.4845)$ & $(-0.0957)$ & $(0.0898)$ & $\mathbf{( 0 . 8 4 0 5 )}$ & $(0.2346)$ & $(0.1850)$ \\
\hline \multirow{2}{*}{ Plant height } & -0.0029 & 0.0389 & 0.0011 & 0.0341 & $\mathbf{0 . 1 3 5 3}$ & 0.0396 \\
& $(0.0019)$ & $(-0.0587)$ & $(-0.0004)$ & $(-0.0523)$ & $(-\mathbf{0 . 1 8 7 5})$ & $(-0.0567)$ \\
\hline \multirow{2}{*}{ No. of seed/Panicle } & -0.0041 & -0.0616 & -0.1378 & 0.0583 & 0.0984 & $\mathbf{0 . 3 3 5 6}$ \\
& $(-0.0131)$ & $(-0.1403)$ & $(-0.3034)$ & $(0.1602)$ & $(0.2203)$ & $(\mathbf{0 . 7 2 8 1})$ \\
\hline \multirow{2}{*}{ Seed yield/ha } & -0.1434 & -0.1311 & 0.3261 & 0.2382 & 0.2355 & 0.1810 \\
& $(-0.1566)$ & $(-0.1550)$ & $(0.3926)$ & $(0.3395)$ & $(0.2901)$ & $(0.2060)$ \\
\hline \multirow{2}{*}{ Partial R $\mathrm{R}^{2}$} & -0.0351 & 0.0183 & 0.1955 & 0.0402 & 0.0318 & 0.0607 \\
& $(-0.2044)$ & $(-0.0164)$ & $(0.5714)$ & $(0.2853)$ & $(-0.0544)$ & $(0.1500)$ \\
\hline
\end{tabular}

Residual Effect (Phenotypic) $=0.8298$

Residual Effect (Genotypic) $=0.5181$

Figures in parenthesis are genotypic effects

Table 5: Estimates direct and indirect effects between yield and yield components

\section{Conclusion}

Studies on correlation and path analysis in medium duration rice varieties showed that some of the characters could not produce significant correlation with single plant yield which might be due to high negative direct effects. Critical analysis of results obtained from character association and path analysis indicated that days to $50 \%$ flowering recorded positive and significant correlation with plant height, 1000 seed weight and panicle length. 1000 seed weight had maximum positive effect on grain yield followed by panicle length. Hence selection for the traits with high heritability coupled with high genetic advance like days to $50 \%$ flowering, plant height, number of effective tiller per plant, panicle length, number of filled grains per panicle, 1000 seed weight and yield could bring improvement in yield and yield components of medium duration rice varieties.

\section{Acknowledgement}

I acknowledge sincere thanks to Dr. T.Srinivas, Associate Professor and Head, Department of Genetics and Plant Breeding, 
Mahanandi Agriculture College, Acharya N.G.Ranga Agriculture University, Andhra Pradesh for his immense suggestions and guidance in carrying out the work.

\section{References}

1. Fiyaz RA, Ramya KT, Chikkalingaiah, Ajay BC, Gireesh C (2011) Genetic variability, correlation and path coefficient analysis studies in rice (Oryza sativa L.) under alkaline soil condition. Electron J Plant Breed 2: 531-7.

2. Bhadru D, Lokanadha Reddy D, Ramesh MS (2011) Correlation and path coefficient analysis of yield and yield contributing traits in rice hybrids and their parental lines. Electron J Plant Breed 2: 112-6.

3. Krishna L, Raju CHD, Raju CHS (2008) Genetic variability and correlatin in yield and grain quality character of rice germplasm. Andhra Agric J 55:276-9.

4. Adilakshmi D, Girijarani M (2012) Variability, character association and path analysis in rice under submergence. Crop Res 44: 146-51.

5. Bakela BD, Rakhi S, Naveen GK, Kundur PJ, Shasidhar HE (2013) Estimation of genetic variability and correlation studies for grain zine concentrations and yield related traits in selected rice (Oryza sativa L.) genotypes. Asian J Exp bio sci 4: 345-51.

6. Sudharani M, Reddy PR, Reddy GH, Raju CS (2013) Correlation and path coefficient analysis for yield and physiological attributes in rice (Oryza sativa L.) hybrids under saline soil conditions. Journal of research J Res ANGRAU 41: 105-180.

7. Minnie CM, Reddy TD, Raju CS (2013) Correlation and path analysis for yield and its components in rice (Oryza Sativa L.). J Res ANGRAU 41: $132-4$.

8 Singh PK, Dhakad BK, Singh AK (2012) Genetic variability and association analysis in rice (Oryza sativa L.) treated with trichoderma harzianum. Crop Res 44: 141-5.

9. Haider Z, Khan AS, Zia S (2012) Correlation and Path Coefficient Analysis of Yield Components in Rice (Oryza sativa L.) under Simulated Drought Stress Condition. American-Eurasian J Agric \& Environ Sci 12: 100- 4.

10. Selvaraj CI, Nagarajan P, Thinagaran K, Bharathi M, Rabindran R (2011) Genetic parameters of variability, correlation and path coefficient studies for grain yield and other yield attributes among rice blast disease resistant genotype of rice (Oryza sativa L.). AJB 10: 3322-34.

11. Singh, RK, Chaudhary BD (1995) Biometrical methods in quantitative genetic analysis In: Biometrical methods in quantitative genetic analysis. Kalyani Publishers. New Delhi, India.

12. Dewey JR, Lu KH (1959) Correlation and path coefficient analysis of components of crested wheat grass seed production. AJ 51: 515-8

13. Sivaparvathi P, Rao SV, Ahamed ML, Kumar AP (2011) Variability, heritability and genetic advance for yield and grain quality characters in rice. Andhra Agric J 58:116-8

14. Sameera SK, Rajesh AP, Jayalakshmi V, Nirmala PJ, Srinivas T (2015) Genetic variability studies for yield and yield components in rice (Oryza sativa L.) Electron J Plant Breed 6: 269-73.

15. Singh M, Kumar K, Singh RP (2007) Study of co-efficient of variation, heritability and genetic advance in hybrid rice. Oryza-An Int J on Rice 44:160-2.

16. Lal M, Chauhan DK (2011) Studies of genetic variability, heritability and genetic advance in relation to yield traits in Rice. Agric Sci Digest 31: $220-2$.

17. Prasad SG, Sujatha M, Rao LVS, Chaithanya U (2013) Studies on variability heritability and genetic advance for quantitative characters in Rice (Oryza Sativa L.). Ann Biol Res 4: 372-75.

18. Burton G (1952) Variability, heritability and genetic advance in mulberry (Morus spp.) for growth and yield attributes. In: Quantitative inheritance in grasses, Proc $6^{\text {th }}$ Grassesland Congr J 1:277-83.

19. Padmaja D, Radhika K, Subba Rao LV, Padma V (2011) Correlation and path analysis in rice germplasm. Oryza-An Int J on Rice 48: 69-72

20. Ravindra Babu V, Sherya K, Kuldeep Singh D, Usharani G, Siva SA (2012) Correlation and path analysis studies in Popular rice hybrids of India. IJSRP 2: 276-80.

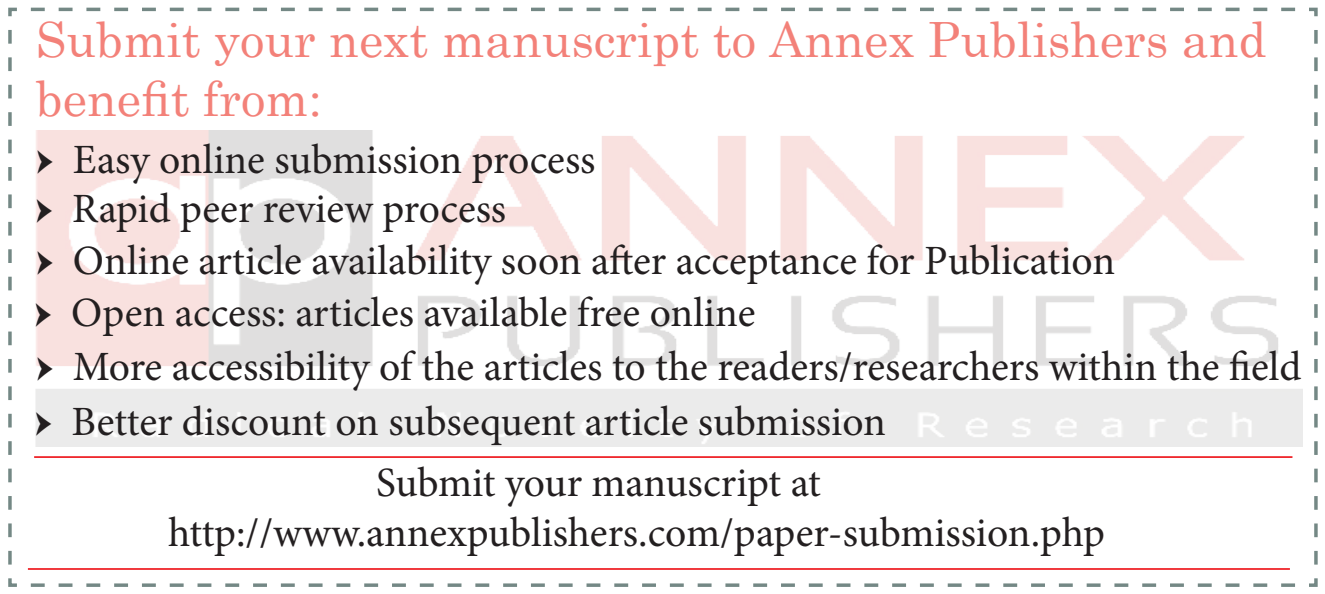

